\begin{tabular}{lll}
\hline institute & $\begin{array}{c}\text { CARADDE: Jurnal Pengabdian Kepada Masyarakat } \\
\text { https://journal.ilininstitute.com/index.php/caradde } \\
\text { Volume 2 | Nomor 1 I Agustus | } 2019 \\
\text { e-ISSN: 2621-7910 dan p-ISSN: 2621-7961 }\end{array}$ & Iiin \\
& DOI: https://doi.org/10.31960/caradde.v2i1.127 & \\
\hline
\end{tabular}

\title{
Pengembangan Listrik Tenaga Surya bagi Pedagang Kuliner
}

\author{
Lory Marcus Parera ${ }^{1}$, Johanis Tupalessy ${ }^{2}$, Roland Kastnaja ${ }^{3}$
}

\section{Keywords : \\ Tenaga Surya; \\ Hemat Energi; \\ Kuliner.}

\section{Corespondensi Author}

Bidang Ilmu : Teknik Elektro, Institusi : Politeknik Negeri Ambon Alamat Penulis : Jl. Gang Raja RT 023/RW 005 Passo - Ambon

Email: lory.parera75@gmail.com

\section{History Artikel}

Received: April-2019;

Reviewed: Mei -2019

Accepted: Juni-2019

Published: Juni-2019

\begin{abstract}
Abstrak. Tujuan kegiatan pengabdian yang dilaksnakan adalah memberikan pemahaman dan pengetahuan pentingnya penggunaan energi baru terbukan listrik tenaga surya (PLTS) bagi pedangan kuliner. Metode yang digunakan yaitu dilakukannya survey untuk mengetahui sejauh mana pedagang tahu tentang listrik tenaga surya dan memberikan ceramah serta demontrasi cara menggunakan lampu tenaga surya pada tempat usahanya. Sebesar 99,7\% menggunakan sumber listrik PLN, sedangkan 0,33\% menggunakan sumber accu. Untuk mengurangai pemakain listrik dari PLN, maka solusi yang tepat adalah dapat menggunakan sumber energi matahari sebagai pembangkit tenaga listriknya atau lampu tenaga surya hemat listrik (LTSHE). Kapasitas lampu tenaga surya hemat energi terdiri dari 3 buah lampu dengan masingmasing lampu 3 watt. Lampu 3 waat setara lampu 15 waat jenis lain.Hasil yang diperoleh dari kegiatan ini adalah pedagang dapat memiliki pengetahuan tentang pentingnya energi matahari dapat dimanfaatkan sebagai sumber energi listrik sehingga mengurangi tingkat ketergatungan dari sumber listrik PLN dan menikmati dampak pemasangan lampu LTSHE pada tempat usahanya.
\end{abstract}

\section{PENDAHULUAN}

Energi listrik merupakan salah satu faktor pendukung penting bagi kehidupan manusia karena banyak sekali peralatan yang biasa kita gunakan menggunakan listrik sebagai sumber energinya. Sejak adanya listrik itulah mulai bermunculan alat bantu manusia yang menggunakan listrik untuk mempermudah pekerjaan manusia. Alat bantu manusia dari masa kemasa mengalami perkembangan yang sangat luar biasa dan sangat canggih. Manfaat listrik bagi kehidupan manusia antara lain, sebagai penerangan lampu dirumah, Untuk menyalakan televisi, radio, memasak dan masih banyak kegunaan listrik dalam kehidupan kita sehari-hari.

Pasokan listrik Rumah Tinggal selama ini disuplai oleh PLN dengan waktu operasi 24 jam, dibutuhkan suplai tambahan energi terbarukan untuk menjadikan rumah yang mempunyai energi mandiri. Pasokan listrik rumah tinggal dapat menggunakan skema pembangkit listrik hibrida PLTSPLTB-PLN. Sistem PLTS dimanfaatkan untuk mengurangi pemakaian energi yang di suplai PLN. (Alfanz 2015)

Sasaran pemanfaatan listrik surya adalah elektrifikasi untuk daerah terpencil sebagai pemerataan hasil pembangunan, pemanfaatan energi lokal sebagai pelaksana kebijaksanaan pemerintah tentang 
penggunaan energi terutama non BBM, dan sebagai energi alternatif untuk keperluan cadangan. (Dewi 2013).

Panel surya merupakan pembangkit listrik yang mampu mengkonversi penyinaran matahari yang diubah menjadi arus listrik. Panel surya juga memiliki kelebihan menjadi sumber energi yang praktis dan ramah lingkungan mengingat tidak membutuhkan transmisi seperti jaringan listrik konvensional, karena dapat dipasang secara modular di setiap lokasi yang membutuhkan.

Sel surya disusun dengan menggabungkan silikon jenis $\mathrm{p}$ dan jenis $\mathrm{n}$. Silikion jenis $\mathrm{p}$ adalah silikon yang bersifat positif akibat dari kekurangan elektron sedangkan silikon jenis $\mathrm{n}$ adalah silikon yang bersifat negatif akibat dari kelebihan elektron. Ketika menerima (dikenai) radiasi surya (berupa foton) pada keduanya (silikon jenis $p$ dan n) terbentuk positif (hole) dan negatif (elektron). Dengan menyambungkan kedua jenis silikon melalui suatu penghantar luar maka terjadi beda potensial antara keduanya dan mengalirkan arus searah seperti pada gambar di bawah ini. (Abubakar Lubis, 2006)

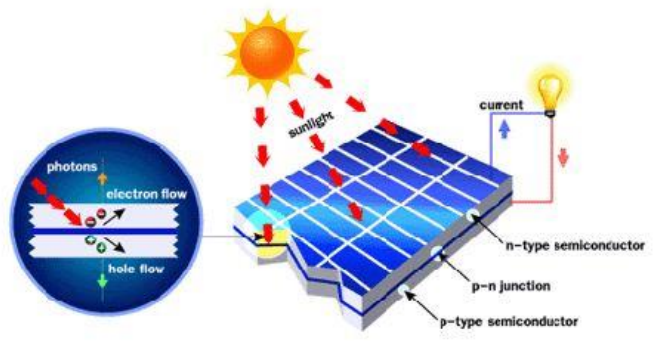

Gambar 1. Prinsip kerja sel fotovoltaik

Sel surya yang digunakan di orbit terkena lingkungan radiasi terutama proton dan elektron energi tinggi. Partikel ini menurunkan parameter output sel surya. Tujuan dari pekerjaan ini adalah untuk mencirikan efek pertemuan elektron iradiasi pada parameter J (V) karakteristik dan output dari sel surya $\mathrm{GaAs}$ dengan simulasi numerik. (H. Mazouz 2013)

\section{Faktor-faktor yang Mempengaruhi Solar Cells Panel}

Empat hal utama yang mempengaruhi unjuk kerja/ performansi dari modul solar cells panel :

\section{Resistansi Beban}

Effisiensi paling tinggi adalah saat solar panel cell beroperasi dekat pada maximum power point.Pada contoh di atas, tegangan baterai harus mendekati tegangan Vmp. Apabila tegangan baterai menurun di bawah Vmp, ataupun meningkat di atas Vmp, maka effisiensi nya berkurang.

\section{Intensitas}

Cahaya Matahari Semakin besar intensitas cahaya matahari secara proposional akan menghasilkan arus yang besar. Seperti gambar berikut, tingkatan cahaya matahari menurun, bentuk dari kurva I-V menunjukkan hal yang sama, tetapi bergerak ke bawah yang mengindikasikan menurunnya arus dan daya. Voltase adalah tidak berubah oleh bermacammacam intensitas cahaya matahari.

\section{Suhu solar cell panel}

Sebagaimana suhu solar cell panel meningkat diatas standar suhu normal 25 derajat Celcius, efisiensi solar cell panel modul effisiensi dan tegangan akan berkurang.

\section{Shading/ Teduh/ Bayangan}

Shading adalah dimana salah satu atau lebih sel silikon dari solar cell panel tertutup dari sinar matahari. Shading akan mengurangan pengeluaran daya dari solar cell panel. Beberapa jenis solar cell panel module sangat terpengaruh oleh shading dibandingkan yang lain. (Zian Iqtimal, 2018)

\section{Karakteristik Arus - Tegangan}

Untuk menurunkan atau mendapatkan karakteristik arus-tegangan, kita harus memperhatikan diagram pita energi dari suatu p-n junction yang kena radiasi surya, seperti pada rangkaian ekivalen gambar 2 . (Abubakar Lubis, 2006)

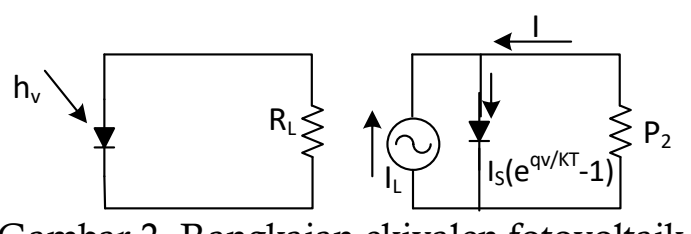

Gambar 2. Rangkaian ekivalen fotovoltaik

Karakteristik I-V suatu solar sel fotovoltaik disberikan dalam persamaan :

$$
\mathrm{I}=\mathrm{I}_{\mathrm{S}}\left(\mathrm{e}^{\mathrm{qv} / \mathrm{KT}}-1\right)-\mathrm{I}_{\mathrm{L}}
$$

Perangkat untuk mengukur kurva I-V dari sel surya tunggal dan dapat digunakan 
untuk pengukuran otomatis dengan waktu pemicu. Hal ini memungkinkan karakterisasi jangka panjang dari sel surya tunggal di bawah kondisi lingkungan nyata termasuk mengubah illimunation dan temperatureas sebagai bayangan atau efek polusi sel. (Mayer 2015).

Jenis panel sel surya. Panel sel surya mengubah intensitas sinar matahari menjadi energi lsitrik. Panel sel surya menghasilkan arus yang digunakan untuk mengisi batere. Panel surya terdi dari photovoltaic, yang menghasilkan listrik dari intensitas cahaya, saat intensitas cahaya berkurang(berawan, mendung, hujan) arus listrik yang dihasilkan juga berkurang. Dengan memperluas panel surya berarti menambah konversi tenaga surya. Umumnya panel sel surya dengan ukuran tertentu memberikan hasil yang tertentu juga. Contohnya ukuran a $\mathrm{cm} \times \mathrm{b} \mathrm{cm}$ menghasilkan listrik DC (Direct Current) sebesar x watt per hour. (Dzulfikar, 2016).

(Mono-crystalline) Panel ini adalah panel surya yang paling efisien, yaitu menghasilkan daya listrik persatuan luas yang paling tinggi. Memiliki efisiensi sampai dengan $15 \%$. Kelemahan dari panel jenis ini adalah tidak akan berfungsi di tempat yang cahaya mataharinya kurang (teduh), kestabilannya akan turun drastis dalam cuaca berawan.

(Poly-crystalline) Merupakan panel surya yang memiliki susunan kristal acak. Type polikristal memerlukan luas permukaan yang lebih besar dibandingkan dengan jenis monokristal untuk menghasilkan daya listrik yang sama, akan tetapi dapat menghasilkan listrik dalam keadaan cuaca berawan.

Pemasangan sebuah panel sel surya dengan posisi tegak lurus terhadap arah sinar matahari dilakukan untuk mengetahui keluaran maksimum, sedangkan untuk mengetahui pengaruh arah sinar matahari terhadap keluaran panel dilakukan dengan merubah arah panel sel surya tiap $10^{\circ}$ hingga mencapai sudut $45^{\circ}$ terhadap sudut datang matahari. (Ramadhan 2016)

Besarnya pemakaian energi listrik oleh setiap pelanggan dapat diketahui oleh pihak PLN dari alat yang namanya KWh meter. Kilo watt hour adalah suatu alat untuk mengukur jumlah pemakaian energi listrik dalam setiap satu jam. Pada awalnya fungsi KWh meter untuk menghitung pemakaian energi listrik secara analog. Dalam perkembangan teknologi memungkinkan kita untuk mengembangkan KWh yang sudah ada, supaya pelanggan listrik bisa mengetahui berapa rupiah yang harus dibayarkan setiap bulan kepada PLN.

Berbeda dengan pedangan kuliner di kota Ambon, hampir sebagian besar pedang kuliner menggunakan listrik sebagai penerangan untuk menjual dagangan mereka. Dari hasil pantauan di lapangan pedangan kuliner 99\% di kota Ambon menggunakan listrik yang di sambungkan dari rumah-rumah yang berdekatan dengan tempat usaha mereka. Para pedangan akan membayar biaya tambahan bagi pemilik rumah yang berlangganan listrik di PLN.

Berapa pedangan atau sekitar $5 \%$
menggunakan accu untuk menghasilkan sumber energi DC, namun masih sangat terbatas daya yang dihasilkan dari sumber aki tersebut. Sementara pemakaian energi listrik bisa melebihi kapasitas yang dihasilkan dari sumber aki. Untuk memenuhi kebutuhan energi dari pedagang tersebut banyak cara yang dihalalkan untuk mendapatkan energi listrik baik secara murah bahkan gratis, bahkan ada sebahagian pedangan yang melakukan tindakan pencurian listrik yang disambungkan secara ilegal. Hal ini tentunya tidak boleh terjadi sebab secara teknis dapat berbahaya bagi keselamatan pedangan. Dari sisi aturan mereka telah melakukan pelanggaran terhadap undang-undang ketenagalistrikan.

Untuk mengurangi dan bahkan menghilangkan cara berpikir dan tindakan yang dilakukan oleh sebahagian pedagang ini, maka solusi yang ditawarkan adalah menyediakan penggunaan listrik mandiri yang memanfaatkan energi surya matahari sebagai sumber alternatif penyediaan energi listrik.

\section{METODE}

Metode pengabdian kepada masyarakat yang dilakukan adalah untuk mengatasi permaslahan mitra dan dilakukan pendekatan sebagai berikut :

Berdasarkan uraian pada analisis situasi, maka penulis dapat membangun kerangka pikir dalam bentuk blok diagram kerangka pemecahan masalah sebagai berikut : 


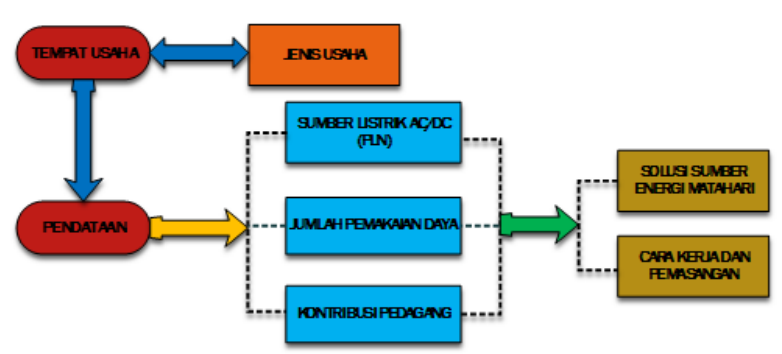

Gambar 3. Kerangka pemecahan masalah

Dalam kerangka pemecahan masalah yang perlu dilakukan adalah indentifikasi tempat usaha dan jenis usaha, dimana pendataan ini bermaksud untuk mendapatkan data dari mana berasal sumber listrik yang digunakan di tempat usaha tersebut. Data ini meliputi sumber listrik apakah dari PLN atau sumber Accu, besar pemakaian daya listrik dan besar kontribusi bulanan yang di bayar ke pemilik sumber listrik

Realisasi Pemecahan Masalah. Kegiatan pengabdian masyarakat ini akan dilaksanakan langsung bersama mitra di tempat usahanya, sehingga pedagang kuliner merasakan manfaat sumber listrik yang berasal dari panas matahari Kegiatan pengabdian masyarakat ini akan dilaksanakan langsung bersama mitra di tempat usahanya, sehingga pedagang kuliner merasakan manfaat sumber listrik yang berasal dari panas matahari.

Metode yang dilakukan pada kegiatan pengabdian ini adalah : (1) Survey lokasi tempat usaha kuliner; (2) Melakukan pendekatan dan cara pedagang mendapatkan sumber listrik; (3) Pendataan jumlah tempat usaha; (4) Pemetaan lokasi pedagang dan besar daya yang dibutuhkan; (4) Melakukan pemasangan PLTS sebagai sumber energi alternatif. Hasil pembuatan dan pemasangan PLTS akan diserahkan kepada mitra sebagai bentuk Penerapan pemanfaatan energi baru terbarukan kepada masyarakat khususnya mitra.

\section{HASIL DAN PEMBAHASAN}

Besar daya yang dihasilkan panel surya bergantung pada intensitas radiasi matahari yang mengenai permukaan panel surya. Panel surya yang digunakan sebagai sumber energi alternatif dengan daya maksimum $50 \mathrm{Wp}$ memiliki efisiensi sebesar $12,25 \%$. Daya yang dihasilkan oleh panel surya dipengaruhi oleh intensitas radiasi matahari yang mengenai permukaan panel surya. (Zian Iqtimal, 2018)

Ada beberapa aplikasi teknologi PV yang saat ini sedang dikembangkan antara lain Solar Home System, lampu penerangan tenaga surya, dan pompa air tenaga surya. Solar Home System Solar Home System (SHS) biasanya diterapkan pada rumah tinggal, tempat ibadah, puskesmas, dan instansi pemerintah di daerah terpencil seperti pedesaan. Komponen utama yang digunakan adalah modul surya, baterai/aki, regulator baterai, inverter, dan kabel. Lampu jalan tenaga surya Lampu jalan tenaga surya sangat besar manfaatnya dalam rangka penghematan energi listrik PLN yang membutuhkan BBM itu. Lampu jalan jenis ini sangat cocok untuk daerah terpencil yang jauh dari instalasi listrik PLN. (Hasan 2012)

Untuk memenuhi permintaan beban dasar, rating daya nominal untuk modul PV ditetapkan pada $10 \mathrm{~kW}$, sebuah studi kasus praktis digunakan untuk menguji dan memverifikasi konsistensi parameter dioda tunggal model sel surya. Studi banding dilakukan untuk sebuah pendekatan teknik estimasi yang efektif. (AlRashidi 2013)

Oleh karena itu, energi listrik merupakan salah satu faktor yang sangat penting dalam kehidupan manusia, baik energi listrik yang dipakai di rumah-rumah, kantor, penerangan jalan dan lain-lain. Energi listrik yang digunakan ini berasal dari sumber pembangkit konvensional seperti PLTD.

Salah satu prasyarat dalam perluasan pemanfaatan PLTS adalah ketersediaan peralatan dan komponen PLTS tersebut. Ketersediaan sistem PLTS di Indonesia yang kapasitasnya sesuai dengan kebutuhan rumah tangga di perkotaan. Ketersediaan yang dimaksud meliputi data tentang kapasitas dan vendor dari komponen PLTS. (Kumara 2010)

Sumber pembangkitan tenaga listrik yang memasok daya listrik kepada masyarakat di kota Ambon $100 \%$ berasal dari pembangkit listrik tenaga diesel (PLTD).

Beberapa lokasi yang dijadikan sebagai tempat jualan kuliner seperti depan MCM, badan jalan di Batu Meja, depan Ambon Plaza dan J1. A.M. Sanagdji.

Pada lokasi-lokasi yang disebutkan di atas, data-data penggunaan sumber listrik dapat disajikan pada lampiran. 
Data-data yang disajikan pada tabel (lampiran), menunjukkan bahwa 99,9 \% sumber listrik yang digunakan pedagang untuk berjualan menggunakan sumber PLN dengan menyambungkan sumber listrik dari rumah penduduk dengan perjanjian haru membayar iuran listrik setiap bulan.

Pada pelaksaan kegiatan pengabdian masyarakat ini, tim pengabdian memperkenalkan penggunaan tenaga surya sebagai sumber pembangkit alternatif atau yang disebut dengan lampu tenaga surya hemat energi (LTSHE).

Lampu tenaga surya hemat energi (LTSHE) memiliki dua dasar hukum yang ditetapkan dalam Peraturan Presiden Nomor 17 Tahun 2017 tentang Penyediaan LTSHE bagi Masyarakat yang belum mendapatkan akses listrik dan Peraturan Metnteri ESDM Nomor 33 Tahun 2017 tentang tata cara Penyediaan LTSHE bagi masyarakat yang belum mendapatkan akses listrik.

Salah satu kegiatan yang dilakukan bersama mitra yaitu di tempat usaha kuliner di $\mathrm{J}$, Ahmad Yani Ambon. Yang dilakukan adalah memberikan pengetahuan tentang lampu tenaga surya hemat energi kepada para pedangan, cara penggunaan dan cara pemasangan mulai dari panel surya sampai dengan pemasangan lampu-lampu.

Satu set lampu tenaga surya hemat energi terdiri dari 5 komponen yaitu modul surya dengan kapasitas $20 \mathrm{Wp}, 3$ buah lampu Ligth Emiting Dioda (ligth bulb), 1 buah remote kontrol, 3 buah kabel penghubung sepanjang 5 meter, pusat jaringan (charging hub), USB kabel hub dan mobile phone charging hub.

Secara skematik lampu tenaga surya hemat energi dipasang seperti pada gambar di bawah ini :

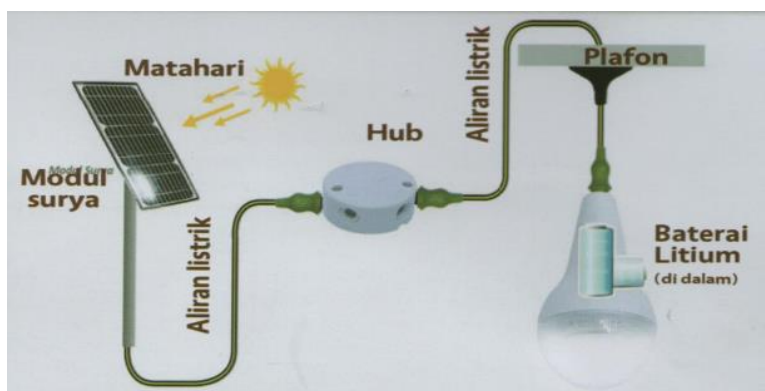

Gambar 4. Skematik lampu tenaga surya

Jika dibandingkan dengan komponen PLTS yang umumnya digunakan, instalasi pembangkit listrik tenaga surya terpusat memiliki komponen beragam tergantung jenis baterai yang digunakan dalam sistem tersebut. Secara umum PLTS terpusat memiliki beberapa komponen yaitu, modul surya, baterai,combiner box, monitoring sistem divice, tiang distribusi, sistem penangkal petir, energy limiter, penyangga modul surya, solar charger controller, panel distribusi, power cable, inverter.

Pada pengabdian kepada masyarakat ini, lokasi dan jumlah pedagang kuliner di data untuk mengetahui dari mana sumber energi listrik di pasok, apakah berasal dari rumahrumah penduduk atau ada pedangan yang menggunakan sumber energi baru terbarukan dan bahkan apakah ada yang menggunakan sumber dc atau acuu.

Hasil data yang diperoleh terdiri dari beberapa lokasi pedangan kuliner yang terpusat, artinya jumlah pedagang yang menjalani usaha lebih dari 10 tempat usaha. Lokasi-lokasi yang menjadi objek pengabdian yaitu lokasi MCM terdiri dari 20 tempat usaha, Batu Meja 10 tempat usaha, AM. Sangaji 24 tampat usaha. Tempat-tempat usaha ini menggunakan sumber lampu yang berbeda-beda rata-rata mulai dari 10 watt 200 watt. Jadi hampir sekitar 99,97 \% menggunakan daya listrik yang berasal dari sumber PLN. Sedangkan 0,03 \% menggunakan sumber listrik accu. Sumber listrik yang digunakan berasal dari pemilik rumah atau toko-toko yang ada disekitar tempat usaha tersebut, kontribusi atau iuran yang dibayarkan kepada pemilik sumber listrik sebagai jasa kisaran $150-480$ ribu per bulan.

Dari sejumlah tempat usaha bagi pedagang kuliner, lokasi yang menjadi tempat untuk dilakukan pemberian informasi dan pemahanan tentang sumber tenaga surya yaitu pada tempat yang berlokasi di Jl, Ahmad Yani, Batu Meja. Para pedagang disekitar lokasi tersebut berjumah 10 tempat usaha yang menggunakan sumber listrik temporer. Penggunakan lampu penerangan berkisar 5-82 waat, dengan iuran perbulan sekitar Rp. 150.000. Pada pengabdian masyarakat ini, dijelaskan pemahaman mengenai pentingnya sumber tenaga matahari yang dapat menghasilkan tenaga listrik, cara pemasangan untuk mendapatkan energi langsung dari matahari dan cara penggunaanya pada tempat usaha. Lampu tenaga surya hemat energi sangat tepat 
Caradde: Jurnal Pengabdian Kepada Masyarakat

Vol 2 No 1, Agustus 2019

digunakan pada tempat usaha yang dilakukan pada malam hari, kapasitas lampu tenaga surya hemat energi terdiri dari 3 buah lampu

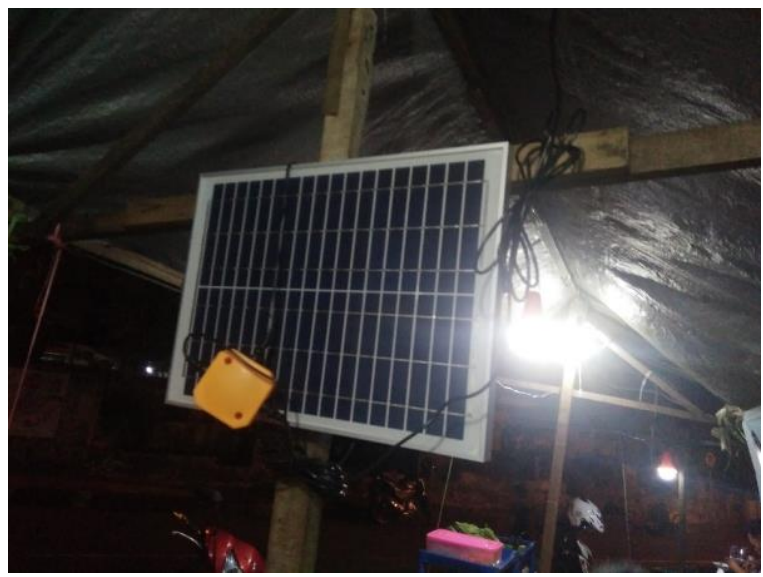

dengan masing-masing lampu 3 watt. Lampu 3 waat ini setara lampu jenis philips 15 waat.

Gambar 5. Tim Memberikan Penjelasan Penggunaan Lampu Hemat Energi

\section{SIMPULAN DAN SARAN}

Berdasarkan hasil Pengabdian masyarakat yang dilakukan pada tempat usaha pedagang kuliner di kota Ambon, maka dapat disimpulkan bahwa terdapat 4 lokasi tempat usaha yang terpusat, dimana para pedagangnya melakukan aktivitas usahanya dengan menggunakan energi listrik 99,97\% yang bersumber dari PLN, sedangkan 0,33 \% menggunakan sumber accu.

Untuk mengurangi penggunaan energi listrik dari PLN, maka dapat digunakan lampu tenaga surya hemat energi (LTSHE) sebagai alternatif, karena sangat praktis dan dapat digunakan pada setiap keadaan.

Dengan demikian, kegiatan lanjutan untuk mensosialisasikan pengguanan lampu tenaga surya hemat energi (LTSHE) kepada pedangan kuliner di Kota Ambon perlu melibatkan pemerintah kota Ambon agar lampu tenaga surya hemat energi dapat digunakan secara massal dengan bantuan APBD kota Ambon.

\section{DAFTAR RUJUKAN}

Abubakar Lubis, dkk. (2006). Listrik Tenaga Surya Fotovoltaik. Jakarta: BPPT Press.

Alfanz, Rocky. (2015). "Rancang Bangun Penyedia Energi Listrik Tenaga Hibrida (PLTS-PLTB-PLN) Untuk
Membantu Pasokan Listrik Rumah Tinggal ." SETRUM.

AlRashidi, M. R., K. M. El-Naggar, M. F. AlHajri. (2013). "Solar Cell Parameters Estimation Using Simulated Annealing Algorithm." World Academy of Science, Engineering and Technology International Journal of Electrical and Computer Engineering.

Anwar Ilmar Ramadhan, Ery Diniardi, Sony Hari Mukti. (2016). "Analisis Sedain Sistem Pembangkit Listrik Tenaga Surya Kapasitas 50 WP." http://ejournal.undip.ac.id/index.php/te knik.

Dewi, Arfita Yuana. (2013). "Pemanfaatan Energi Surya sebagai Suplai Cadangan pada Laboratorium Elektro Dasar di Institut Teknologi Padang ." Teknik Elektro.

Dzulfikar, Dafi., Wisnu Broto (2016). "Optimalisasi Pemnafaatan Energi Listrik Tenaga Surya Skala Rumah Tangga." Prosiding Seminar Nasional Fisika (E-Journal) SNF2016.

H. Mazouz, A., Belghachi, F. Hadjaj (2013). "Solar Cell Degradation by Electron Irradiation Effect of Irradiation Fluence ." World Academy of Science, Engineering and Technology International Journal of Physical and Mathematical Sciences.

Hasan, Hasnawiya. (2012). "Perencanaan Pembangkit Listrik Tenaga Surya di 
Parera, Tupalessy, Kastnaja. Pengembangan Listrik Tenaga Surya

Pulau Saugi." Jurnal Riset dan Teknologi ((JRTK).

Iqtimal, Zian., Ira Devi Sara dan Syahrizal (2018). "Aplikasi Sistem Tenaga Surya Sebagai Sumber Tenaga Listrik Pompa Air." Kitektro.

Kumara, Nyoman S. (2010). "Pembangkit Listrik Tenaga Surya Skala Rumah Tangga Urban dan Ketersediaanya di Indonesia ." Teknik Elektro.

Mayer, Christoph., Dominik Holzmann (2015). "An Approach On The Design of a Solar Cell Characterization Devive." World Academy of Science, Engineering of Technology International Journal of Energy and Power Engineering.

Ramadhan, Anwar Ilmar. (2016). "Analisis Desain Sistem Pembangkit Listrik Tenaga Surya Kapasitas 50 WP ." Teknik 59-63. 